\title{
Association of low birth weight with undernutrition in preschool-aged children in Malawi
}

\author{
Peter Austin Morton Ntenda(i)
}

\begin{abstract}
Background: Malnutrition refers to deficiencies, excesses, or imbalances in a person's intake of energy and/or nutrients. The term malnutrition is a broad term encompassing the three conditions namely undernutrition (micronutrient-related malnutrition), over-nutrition (overweight and obesity), and diet-related non-communicable diseases. Undernutrition is defined as the outcome of insufficient food intake and repeated infectious diseases. Low birth weight (LBW) is cited as a risk factor for mortality and morbidity in young children. However, its association with undernutrition has received little attention. Thus, the current study aimed to examine the relationship between LBW and undernutrition in Malawi.
\end{abstract}

Methods: A cross-sectional study was conducted using data from the Malawi Demographic and Health Survey (MDHS) 2015-16. Children whose Z-scores for each of the following indices height-for-age, weight-for-height, and weight-forage were below the minus two standard deviations (-2SD) from the median of the World Health Organization's (WHO) reference population were considered to be stunted, wasted and underweight, respectively. LBW was defined as babies whose birth weight was less than $2500 \mathrm{~g}$. The multivariate logistic regression models were performed using surveylogistic while controlling various confounding factors in the six different models.

Results: The prevalence of stunted, underweight, wasted, and LBW were reported as follows, 39\%. 11, 2, and 10\% respectively. Compared to children with normal/average birth weight, those with LBW had significantly higher odds of being stunted [adjusted odds ratio (aOR): 1.72; 95\% confidence interval (Cl): 1.35-2.20), underweight (aOR: 2.30; 95\% Cl: 1.68-3.14) and wasted (aOR: 1.47; 95\% Cl: 1.38-4.25) respectively.

Conclusions: LBW was a strong predictor of all the three indices of undernutrition. Interventions that aim at improving the growth and development of children during the early years should consider addressing factors that trigger LBW.

Keywords: Birthweight, Undernutrition, Low birth weight, Child health, Malawi

\section{Background}

Globally, malnutrition is one of the leading causes of morbidity and mortality in preschool-aged children [1-3]. Childhood malnutrition is known to have both acute and chronic consequences that are harmful to the growth and development of pre-school children [2, 3]. Malnutrition refers to deficiencies, excesses, or imbalances in a person's intake of energy and/or nutrients. Malnutrition is a broad term that describes the three conditions, namely

Correspondence: peterantenda@yahoo.com; ntendapeter@gmail.com School of Public Health and Family Medicine, Department of Public Health, College of Medicine, University of Malawi, Private Bag 360, Chichiri, Blantyre 3, Malawi

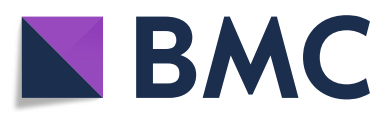

undernutrition including micronutrient-related malnutrition, over-nutrition (overweight and obesity), and diet-related non-communicable diseases [4]. By the end of 2017, the World Health Organization (WHO) estimated that 462 million children below 5 years of age had low weight for their age, whilst 155 million had low height for their age, and 52 million had low weight for their heights [4]. It is known that about half of all mortality in preschool-aged children are due to poor nutrition and the burden is prominent in South Asia and sub-Saharan Africa [2-5]. The causes of undernutrition are complex, multifactorial and poorly understood, however, the United Nations Children's Fund

(C) The Author(s). 2019 Open Access This article is distributed under the terms of the Creative Commons Attribution 4.0 International License (http://creativecommons.org/licenses/by/4.0/), which permits unrestricted use, distribution, and reproduction in any medium, provided you give appropriate credit to the original author(s) and the source, provide a link to the Creative Commons license, and indicate if changes were made. The Creative Commons Public Domain Dedication waiver (http://creativecommons.org/publicdomain/zero/1.0/) applies to the data made available in this article, unless otherwise stated. 
(UNICEF) stated that the immediate causes of malnutrition are the inadequate dietary intakes and frequent illnesses [6,7].

Nutrition constraints remain throughout the life cycle of the human being $[8,9]$. Specifically, the lack of good and balanced nutrition time and again begins in utero among women with poor nutritional status before and in the course of pregnancy and extends throughout the life course. Predominantly, the burden of malnutrition is more pervasive in girls and women through adolescent and adult life [10]. Unfortunately, poor nutrition that occurs in the course of childhood, adolescence, and pregnancy has a negative influence on the birth outcomes, including low birth weight (LBW) [11]. As such, babies who had experienced intrauterine growth retardation (IUGR), have a high risk of being undernourished at birth as well as have a higher likelihood of dying in the neonatal period or later in infancy [11]. Conversely, if those infants progress in life, they do not only have problems in catching up on the lost growth, but are also more likely to experience a variety of developmental problems. Thus, LBW infants have a higher risk of becoming underweight or stunted in early life [11]. Thus, good nutrition is critical for infants' optimal growth and development and has an essential role in shaping their health later in life. Globally, in 2013, the UNICEF reported that approximately $16 \%$ of babies had LBW [12]. Corresponding figures from the WHO revealed that about $14 \%$ of LBW infants resided in Africa [13]. Whereas in Malawi, the prevalence of LBW was estimated at $12 \%$, which is close to those figures estimated at global level as well as in Africa [14]. The goal of the WHO is to achieve a $30 \%$ decrease in the number of newborn with a weight lower than $2500 \mathrm{~g}$ by the year $2025[15,16]$.

Despite the long-standing efforts made by the Malawi government [17] to combat poor nutrition in children under 5 years of age, the rates of malnutrition remain unacceptably high $[14,18,19]$. According to the 2016 national estimates on childhood undernutrition in Malawi, 37\% of young children were stunted, $3 \%$ were wasted, and $12 \%$ were underweight [14]. In many settings, LBW has been reported as a risk factor for mortality and morbidity in young children [20-22]. Even though a number of studies classified LBW as a potential risk factor for malnutrition [23-25], most of these studies did not consider LBW as the main risk factor of importance. Therefore, it remains unknown how and to what extent LBW is related to childhood malnutrition during the early years of life. Given that a certain proportion of children born with LBW (12.3\%) in Malawi [14], the current study was conducted to establish an association between LBW and childhood undernutrition in Malawi.

\section{Methods}

\section{Data source}

The current study utilized a population-based cross-sectional data taken from the Malawi Demographic and Health Survey (MDHS) 2015-16 which was conducted between October 2015 and February 2016. The procedures used in this study can be found in details elsewhere [14]. In brief, the MDHS was designed to yield a nationally representative sample at the national level, residence level (urban-rural) and the regional level). The survey employed a stratified two-stage cluster design. In the first stage, the country was stratified depending upon the place of residence as well as subnational administrative regions to construct stratum. Using the probability proportional to size technique, a certain number of enumeration areas (EAs) from each stratum are drawn. The population size was drawn from Census files. In the second stage, a fixed number of households were selected from EAs using the systematic random sampling technique. In the 2015-16 MDHS, a total of 27,516 households were selected for the sample, of which 26 , 564 were occupied. Of the occupied households, 26,361 were successfully interviewed, for a response rate of 99\%. Secondly, in the interviewed households, 25,146 eligible women were identified for individual interviews. However, interviews were completed with 24,562 women, for a response rate of $98 \%$.

\section{Data collection}

The survey collected weight and height of preschool-aged children in a sub-sample of one-third of the households, regardless of whether their mothers got interviewed or not. Thus, a total of 6033 children under age 5 were eligible for height and weight measurements. The analysis of height-for-age indices include $94 \%$ of eligible children with complete and valid height measurement and age data. Analysis of weight-for-height indices includes $95 \%$ of eligible children with complete and valid height and weight measurements. Analysis of weight-for-age indices includes $96 \%$ of eligible children with complete and valid weight measurement and age data. Thus, the final sample analyzed by the MDHS was 5786. An electronic SECA 878 flat scale was used to collect the weight measurements. Whilst a Shorr Board ${ }^{\circ}$ measuring board was used to estimate the height measurements [14]. Recumbent lengths were measured for children less than 2 years old while standing heights were measured for children aged 24 months or older [14]. The data on height and weight were used to calculate several measures of childhood nutritional status, namely; height-for-age, weight-for-height, and weight-for-age. The socio-demographic information was collected from women of reproductive age (15-49 years) who had children below 5 years prior to the survey by means of personal interviews. 


\section{Inclusion and exclusion}

The current study selected children of age group 6-59 months. Children who were missing measurements on birth weight, weight and height were excluded from the analysis. Children whose households were not sampled for height and weight measurements as well as who had missing data on other covariates were also excluded. In addition, this study only included children whose caregivers had been interviewed. After applying the inclusion and exclusion criteria, which included age restriction, 4047 children under 5 years old were analyzed in this study.

\section{Study variables}

\section{Dependent variable}

Childhood undernutrition was the dependent variable of the present study, and the variable was further disintegrated into three indices, namely stunting (low-heightfor-age), underweight (low-weight-for-age) and, wasting (low-weight-for-height) [14, 19]. Each of these indices is expressed as Z-score from the median of the WHO Child Growth Standards reference population [26]. Particularly, children whose Z-scores for any of these three indices were below minus two standard deviations (-2SD) from the median of the WHO's reference population were considered as stunted, wasted or underweight, respectively [26]. Stunting reflects the linear growth achieved during the pre- and post-natal periods with its deficits indicating long-term, cumulative effects of inadequate nutrition and/or health [27]. Wasting indicates acute or current malnutrition that is the consequence of the poor dietary intake or frequent occurrence of infectious disease [28]. Underweight is influenced by the height and weight of the child and thus it's a combination of stunting and wasting [28].

\section{Main independent variables}

The main dependent variable of the current study was birth weight - expressed in grams (g). According to the WHO and UNICEF, birth weight is defined as the first weight of the live newborn or fetus collected soon after birth $[29,30]$. The MDHS 2015-16 reported that birth weight was recorded from either a written record (child's health cards) or mother's recall. Thus, to limit recall bias, the present study included only children who had valid birth weight recorded in their health cards. All children who did not have valid birth weight recorded in their health cards, children who were not weighed, whose delivery occur in homes or other places were excluded. Using the guidelines set by WHO and UNICEF, the birth weight was categorized as LBW or normal birth weight. LBW was defined as birth weight below $2500 \mathrm{~g}$ i.e. up to and including $2499 \mathrm{~g}$. On the other hand, greater than or equal $2500 \mathrm{~g}$ was classified as normal birth weight [30].

\section{Covariates}

It is known that child undernutrition is the result of multiple and interrelated factors. Therefore, apart from the LBW various control variables were included in the present study following careful review of the relevant literature [3, 31], and were grouped as child biological factors, child health factors, maternal/household factors, household environmental factors, health service and seeking behavior related factors, and community level factors (Table 1). Child biological factors include child's sex (male/female) child's age (<12 months /12-23 months/ 24-35 months /35-47 months/48-59), type of birth (single births/multiple births), preceding birth interval (<24 months/12-47 months/48+ months). Child health factors recent diarrhea (no/yes) and recent fever (no/yes). Maternal factors include, women's age (15-19 years/2024 years $/ 25-29$ years/ 30-34 years/35-49 years), women's education (none/primary/secondary education and higher), body mass index (underweight/ optimal weight/ overweight/or obesity), wealth index (poorest/ poorer/ middle/richer/ richest), number of under-5-year children in the household $(\leq 1 / 2-3 / 4+)$, and amount of media exposure $(0 / 1 / 2 / 3)$. Household environmental factors include the source of drinking water (unimproved/ improved) and sanitation facility (unimproved/improved). Health Service utilization factors include the place of delivery (home and other/hospital/institution) and perceived distance to the health facility (not perceived to be a problem or perceived problem). Community characteristics include place of residence (rural/urban) and region (northern/central/ southern). The household wealth index was generated using a statistical method well-known as principal components analysis (PCA) by the Monitoring and Evaluation to Assess and Use Results Demographic and Health Surveys (MEASURE DHS) [32]. Amount of media exposure was derived from three items namely frequency of reading a newspaper, watching television, and or listening to radio at once a week. The MDHS asked respondents the following questions; (1) Do you read a newspaper or magazine at least once a week, less than once a week or not at all? (2) Do you listen to the radio at least once a week, less than once a week or not at all? And (3) Do you watch television at least once a week, less than once a week or not at all? [14]. Then, the amount of media exposure was calculated by summing up the reported frequency of each media if an activity was performed at least once a week. Furthermore, diarrhea was defined as the passage of three or more loose or liquid stools during a 24-h period while fever was determined by self-reports made by caregivers about the symptoms that had occurred within 2 weeks prior to the survey [14]. Specifically, caregivers were asked; has (NAME) been ill with a fever at any time in the last 2 weeks? And has (NAME) had diarrhea in the last 2 weeks? 
Table 1 Baseline characteristics of the study participants MDHS, 2015-16 ( $n=4047)$

\begin{tabular}{|c|c|c|c|c|}
\hline Characteristic & $\begin{array}{l}\text { Overall sample } \\
n^{k}(\%)^{\prime}\end{array}$ & $\begin{array}{l}\text { Stunted } \\
\%\end{array}$ & $\begin{array}{l}\text { Underweight } \\
\%\end{array}$ & $\begin{array}{l}\text { Wasted } \\
\%\end{array}$ \\
\hline \multicolumn{5}{|l|}{ Outcome variables $^{a}$} \\
\hline \multicolumn{5}{|l|}{ Stunted } \\
\hline No & $2521(61.03)$ & - & - & - \\
\hline Yes & $1526(38.97)$ & - & - & - \\
\hline \multicolumn{5}{|l|}{ Underweight } \\
\hline No & $3551(88.69)$ & - & - & - \\
\hline yes & $496(11.31)$ & - & - & - \\
\hline \multicolumn{5}{|l|}{ Wasted } \\
\hline No & $3933(97.70)$ & - & - & - \\
\hline Yes & $114(2.30)$ & - & - & - \\
\hline \multicolumn{5}{|l|}{ Main independent variable } \\
\hline \multicolumn{5}{|l|}{ Birth weight } \\
\hline Low birthweight ${ }^{b}$ & $399(10.11)$ & $50.63^{*}$ & $23.81^{*}$ & $5.26^{*}$ \\
\hline Normal and above & $3648(89.89)$ & 36.29 & 10.99 & 2.55 \\
\hline \multicolumn{5}{|l|}{ Child characteristics } \\
\hline \multicolumn{5}{|l|}{ Sex of the child } \\
\hline Male & $2005(48.78)$ & $39.30^{*}$ & 12.87 & 3.09 \\
\hline Female & $2042(51.22)$ & 36.14 & 11.66 & 2.55 \\
\hline \multicolumn{5}{|l|}{ Age } \\
\hline $6-11$ & $459(11.70)$ & $22.88^{*}$ & $9.59^{*}$ & $4.58^{*}$ \\
\hline $12-23$ & $926(21.98)$ & 38.88 & 11.45 & 3.46 \\
\hline $24-35$ & $921(22.61)$ & 41.91 & 12.49 & 2.71 \\
\hline $36-47$ & $905(22.98)$ & 43.54 & 14.92 & 2.10 \\
\hline $48-59$ & $836(20.73)$ & 33.61 & 11.48 & 2.03 \\
\hline \multicolumn{5}{|l|}{ Multiple births } \\
\hline Single births & $3927(97.09)$ & $37.08^{*}$ & 12.12 & 2.85 \\
\hline Twins & $120(2.91)$ & 58.33 & 16.67 & 1.67 \\
\hline \multicolumn{5}{|c|}{ Preceding birth interval (months) } \\
\hline$<24$ & $1352(32.50)$ & $40.24^{*}$ & 13.83 & 3.55 \\
\hline $24-47$ & $1624(41.30)$ & 37.93 & 11.88 & 2.46 \\
\hline $48+$ & $1071(26.20)$ & 34.17 & 10.83 & 2.43 \\
\hline \multicolumn{5}{|c|}{ Child health related factors } \\
\hline \multicolumn{5}{|l|}{ Recent diarrhea $^{c}$} \\
\hline No & $3178(78.09)$ & 37.44 & 11.80 & $2.39^{*}$ \\
\hline Yes & $869(21.91)$ & 38.67 & 13.92 & 4.37 \\
\hline \multicolumn{5}{|l|}{ Recent fever ${ }^{d}$} \\
\hline No & $2783(68.01)$ & 37.33 & 11.93 & $2.34^{*}$ \\
\hline Yes & $1264(31.99)$ & 38.53 & 12.97 & 3.88 \\
\hline \multicolumn{5}{|c|}{ Maternal/household Characteristics } \\
\hline \multicolumn{5}{|l|}{ Maternal age (years) } \\
\hline $15-19$ & $239(6.13)$ & $37.24^{*}$ & 10.88 & 4.60 \\
\hline $20-24$ & $1225(29.36)$ & 41.80 & 14.37 & 3.27 \\
\hline $25-29$ & $1008(24.62)$ & 35.12 & 10.42 & 2.78 \\
\hline
\end{tabular}


Table 1 Baseline characteristics of the study participants MDHS, 2015-16 ( $n=4047)$ (Continued)

\begin{tabular}{|c|c|c|c|c|}
\hline Characteristic & $\begin{array}{l}\text { Overall sample } \\
n^{k}(\%)^{\prime}\end{array}$ & $\begin{array}{l}\text { Stunted } \\
\%\end{array}$ & $\begin{array}{l}\text { Underweight } \\
\%\end{array}$ & $\begin{array}{l}\text { Wasted } \\
\%\end{array}$ \\
\hline $30-34$ & $792(20.27)$ & 34.22 & 11.74 & 2.15 \\
\hline $35-49$ & $783(19.63)$ & 38.31 & 12.26 & 2.30 \\
\hline \multicolumn{5}{|l|}{ Maternal education levels } \\
\hline No education & $542(14.16)$ & $46.13^{*}$ & $14.21^{*}$ & 2.03 \\
\hline Primary & $2685(67.47)$ & 38.40 & 12.63 & 2.83 \\
\hline Secondary and above & $820(18.37)$ & 29.88 & 9.76 & 3.29 \\
\hline \multicolumn{5}{|l|}{ Maternal body mass index } \\
\hline Underweight & $229(5.62)$ & $43.67^{*}$ & $20.09^{*}$ & $5.68^{*}$ \\
\hline Optimal weight & $3014(75.00)$ & 39.38 & 12.67 & 2.92 \\
\hline Overweight/obesity & $804(19.32)$ & 29.73 & 8.46 & 1.62 \\
\hline \multicolumn{5}{|l|}{ Wealth index } \\
\hline Poorest & $955(26.09)$ & $44.61^{*}$ & $15.39^{*}$ & 3.35 \\
\hline Poorer & $958(24.69)$ & 41.96 & 13.78 & 2.51 \\
\hline Middle & $800(19.34)$ & 38.50 & 11.50 & 2.63 \\
\hline Richer & $729(17.55)$ & 31.96 & 10.01 & 2.47 \\
\hline Richest & $605(12.34)$ & 25.95 & 8.60 & 3.14 \\
\hline \multicolumn{5}{|l|}{ No of under-5-year children } \\
\hline$\leq 1$ & $1938(47.51)$ & $35.04^{*}$ & $11.56^{*}$ & $2.53^{*}$ \\
\hline $2-3$ & $1776(44.29)$ & 39.36 & 11.88 & 2.87 \\
\hline$\geq 4$ & $333(8.20)$ & 44.44 & 18.32 & 4.20 \\
\hline \multicolumn{5}{|l|}{ Amount of media exposure ${ }^{f}$} \\
\hline 0 & $2621(64.76)$ & $40.02^{*}$ & $13.47^{*}$ & 3.13 \\
\hline 1 & $1112(27.48)$ & 35.25 & 10.97 & 1.98 \\
\hline 2 & $272(6.72)$ & 27.57 & 6.62 & 2.94 \\
\hline 3 & $42(1.04)$ & 23.81 & 7.14 & 4.76 \\
\hline \multicolumn{5}{|c|}{ Household environmental factors } \\
\hline \multicolumn{5}{|l|}{ Source of drinking water } \\
\hline Unimproved & $670(15.88)$ & $41.34^{*}$ & 14.18 & 3.13 \\
\hline Improved ${ }^{9}$ & $3377(84.12)$ & 36.99 & 11.87 & 2.75 \\
\hline \multicolumn{5}{|l|}{ Sanitation facility } \\
\hline Unimproved & $806(20.80)$ & 39.70 & 11.91 & 2.48 \\
\hline Improved $^{\text {h }}$ & $3241(79.20)$ & 37.21 & 12.34 & 2.90 \\
\hline \multicolumn{5}{|l|}{ Health Service utilization } \\
\hline \multicolumn{5}{|l|}{ Place of delivery } \\
\hline Home and other & $335(8.79)$ & 40.30 & $17.01^{*}$ & 3.28 \\
\hline Hospital/institution & $3712(91.21)$ & 37.47 & 11.83 & 2.77 \\
\hline \multicolumn{5}{|c|}{ Perceived distance to health facility } \\
\hline Perceived problem & $1773(40.28)$ & 37.79 & 12.35 & 2.88 \\
\hline Not perceived problem & $2274(59.72)$ & 37.64 & 12.18 & 2.77 \\
\hline \multicolumn{5}{|l|}{ Community characteristics } \\
\hline \multicolumn{5}{|l|}{ Place of residence } \\
\hline Urban & $481(7.91)$ & $27.86^{*}$ & 10.40 & $4.37^{*}$ \\
\hline Rural & $3566(92.09)$ & 39.04 & 12.51 & 2.61 \\
\hline
\end{tabular}


Table 1 Baseline characteristics of the study participants MDHS, 2015-16 ( $n=4047)$ (Continued)

\begin{tabular}{lllll}
\hline Characteristic & $\begin{array}{l}\text { Overall sample } \\
\mathrm{n}^{\mathrm{k}}(\%)^{1}\end{array}$ & $\begin{array}{l}\text { Stunted } \\
\%\end{array}$ & $\begin{array}{l}\text { Underweight } \\
\%\end{array}$ & $\begin{array}{l}\text { Wasted } \\
\%\end{array}$ \\
\hline Geographical region & & & 10.00 & 2.11 \\
$\quad$ Northern & $710(10.81)$ & $31.69^{*}$ & 11.93 & 2.40 \\
Central & $1458(43.18)$ & 40.26 & 13.36 & 3.41 \\
Southern & $1879(46.01)$ & 38.00 & \\
\hline
\end{tabular}

${ }^{\mathrm{a}}$ Each index is expressed in SD from the median of the WHO Child Growth Standards; SD standard deviation, WHO World Health Organization; ${ }^{\mathrm{b}}$ Proportion of births with a reported birth weight $<2500 \mathrm{~g}$ regardless of gestational age; ${ }^{c}$ passage of three or more loose or liquid stools during a $24-\mathrm{h}$ period; ${ }^{\mathrm{d}}$ self-reports by mothers about symptoms that had occurred within 2 weeks prior to the survey; ${ }^{\mathrm{e}}$ weight in kilograms divided by the square of his height in meters $\left(\mathrm{kg} / \mathrm{m}^{2}\right.$ ); ${ }^{f}$ frequency of reading newspaper or magazine, frequency of listening to radio, frequency of watching television.; ${ }^{9}$ improved drinking water (piped water into

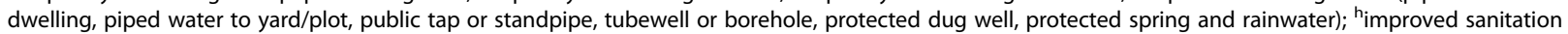
(flush toilet, piped sewer system, septic tank, flush/pour flush to pit latrine, ventilated improved pit latrine, pit latrine with slab, and composting toilet); ${ }^{i}$ government hospital, government health center, government health post/outreach, other public sector, private hospital/clinic, CHAM/MISSION hospital, CHAM/MISSION health Center, BLM, other private medical sector, ${ }^{*}<0.05$; ${ }^{\mathbf{k}}$ Unweighted frequency; 'Weighted percentage

\section{Data analysis}

All data analyses were performed using the statistical analysis software (SAS) for Windows, version 9.4 (SAS Institute, Cary, NC, USA). The survey-specific SAS procedures PROC SURVEYFREQ and PROC SURVEYLOGISTIC for weighting, clustering, and stratification were applied taking into account the hierarchal nature of the survey design [33]. Baseline characteristics were summarized as frequency, weighted percentage, and standard errors. The multivariate analyses were conducted by means of the logistic regression to estimate the effects of the birth weight on the childhood undernutrition while adjusting for six models, namely child's biological, child's health, maternal/households, household environmental, healthcare utilization and community characteristics). Adjusted odds ratios (aORs) and 95\% confidence intervals $(\mathrm{CIs})$ with their $P$-values were calculated. $P$-values of less than 0.05 were considered as statistical significance. The multicollinearity was tested by the use of variance inflation factor and tolerance. The results of collinearity shown no multicollinearity existed in the models (Additional file 1: Table S1). Additional file 2: Figure S1 shows the fit diagnostics for childhood undernutrition, which showed that a lot of variations in the models (stunting, underweight, and wasting) were unexplained (results from the proportion less).

\section{Ethical statement}

The procedures and questionnaires for MDHS 2015-16 were reviewed and approved by the Malawi National Health Sciences Research Committee (NHSRC) and the Institutional Review Board (IRB) of ICF Macro. ICF IRB ensured that the survey complied with the U.S. Department of Health and Human Services regulations for the protection of human subjects (45 CFR 46) [34], while the NHSRC ensured that the survey was conducted in line with Malawian laws and norms [14]. At the beginning of each interview, participants were asked to give verbal and written consent (informed consent). The informed consent statement emphasizes that participation was voluntary and that the respondent may opt to refuse to answer any question. Furthermore, the authors sought permission from the DHS program for the use of the data beyond the primary purpose it was collected.

\section{Results \\ Baseline characteristics of the study population}

A total of 4047 children under 5 years were sampled and analyzed in this study. Baseline characteristics of the study population are presented in Table 1 . Overall, approximately $39 \%$ of children were stunted, while 12 and $2 \%$ were underweight and wasted respectively. In terms of birth weight, a majority of children (about 90\%) were born with normal and above weight. With regards to child biological and health-related factors, more than half (51\%) of the children were female and a majority of them $(97 \%)$ were the products of single births while $41 \%$ of children born between 24 and 47 month intervals. Furthermore, about 22 and 32\% of children had diarrhea and fever episodes in the last 2 weeks respectively. In terms of maternal and household characteristics, approximately $29 \%$ of respondents were distributed in the age group 20-24 years, two-thirds had primary school education and a majority (75\%), had a normal body mass index. Additionally, only $1 \%$ of the participants were exposed to all forms of media (newspaper, radio, and Television). With regards to household environmental and health service utilization factors, a majority of participants $84 \%$, had access to an improved water source while nearly $80 \%$ had improved sanitation facilities. Similarly, a majority of participants $(>90 \%)$ had institutional delivery, whilst $59 \%$ had perceived the distance to the nearest health facility to a big problem. In terms of community characteristics, $46 \%$ of respondents were southern region dwellers and $92 \%$ were rural dwellers. 


\section{Prevalence of undernutrition according to sociodemographic} factors

Table 1, also presents the prevalence of stunting, underweight, and wasting by sociodemographic characteristics. The prevalence of stunting was observed to be significantly high in children with a low birth weight, male children, in children aged 36-47 months, in children who were products of multiple births, in children whose proceeding birth intervals were less than 24 months, inn children whose mothers were 35-49 years, in children whose mothers had no formal education, in children whose mothers had BMI less than $18.5 \mathrm{~kg} / \mathrm{m}^{2}$, in children who were residing in the poorest households, in children whose households had $\geq 4$ under-five children, in children whose households were not exposed to mass media, form in children whose households had no access to improved water sources, in children from rural areas, and in children from central region.

With respect to underweight, the prevalence was observed to be significant high in children with a low birthweight, in children aged 36-47 months, in children whose mothers had no formal education, in children whose mothers had BMI less than $18.5 \mathrm{~kg} / \mathrm{m} 2$, in children who were residing in the poorest households, in children whose households had $\geq 4$ under-five children, in children whose households were not exposed to mass media, and in children who delivered occurred in homes and other places.

In terms of wasting, the prevalence was observed to be significant high in children with a low birthweight, in children aged 6-11 months, in children with an episode of fever in the last 2 weeks, in children with an episode of diarrhea in the last 2 weeks, in children whose mothers had BMI less than $18.5 \mathrm{~kg} / \mathrm{m} 2$, in children whose households had $\geq 4$ under-five children, and in children from rural areas.

Low birthweight and the risk of childhood undernutrition Tables 2, 3 and 4 present the association of the LBW with childhood undernutrition. The unadjusted models (Model 1) showed that compared to children who had normal birth weight those with LBW had an increased odds of being stunted (Crude odds ratio [CrOR]:1.72; 95\% confidence interval $[\mathrm{CI}]: 1.35-2.20)$, of being underweight (CrOR: 2.30; 95\% CI: 1.68-3.14), and, of being wasted (CrOR: 2.42; 95\% CI: 1.38-4.25). The associations remain unchanged even after adjustments for the child's biological factors (Model 2), child's health factors (Model 3), maternal or household factors (Model 4), household environmental factors (Model 5), and health service utilization (Model 6) though with varying strength of odd ratios. The full models (Model 7) showed that the odds increased by $55 \%$ for being stunted (adjusted odds ratio [aOR]: 1.55; 95\% CI: 1.91-2.01), $16 \%$ for being underweight (aOR: 2.16; 95\% CI: $1.56-$
2.99), and 51\% for being wasted (aOR: 2.53; 95\% CI: 1.40-4.57) in children who had LBW compared to those children who were born with normal weight.

\section{Discussion}

It is known that childhood undernutrition is a primary cause of mortality and morbidity in millions of preschoolaged children worldwide [1-3, 35]. Whilst many studies have examined the levels and predictors of childhood undernutrition in different settings $[2,36,37]$, very limited empirical evidence has been reported on the variation of childhood undernutrition across the birth weight status of preschool children. For example, studies in Malawi found that a series of socio-demographic, comorbidities and nutritional characteristics were significantly associated with childhood undernutrition [2, 38-40]. Unfortunately, none of these studies have examined the independent association of birth weight on nutritional status among children below 5 years of age, despite its detrimental consequences. Hence, the present study was conducted to investigate how and to what extent LBW is associated with undernutrition among preschool-aged children in Malawi while adjusting for other known risk factors.

The current study has revealed a strong positive association between LBW and undernutrition among preschoolaged children in Malawi. For instance, the risk of being stunted (57\%), underweight (15\%) and, wasted (51\%) in the course of the early childhood years were found to be higher in children with LBW than in those with normal birth weights even after controlling for other known risk factors for childhood undernutrition in models. Thus, children who have LBW are at increased risk to remain undernourished in the course of the early years of their childhood even after controlling for the child's biological, child's health, maternal/households, household environmental, healthcare utilization and community characteristics. In this study, the pragmatic relationship between birth weight and childhood undernutrition is in line with the results of studies conducted elsewhere [3, 23-25, 41].

For instance, in Malawi increased odds of stunting and underweight were found among children with perceived small sizes at birth than average birth sizes [3]. Similarly, in a study of infant growth patterns and their relations to birth weight in Bangladesh found that birth weight was the most essential predictor of succeeding growth status for the period of infancy [41]. Several epidemiological studies have reported that children with perceived small sizes at birth are often born from households with low socioeconomic status and poor maternal health conditions (i.e. maternal undernutrition) $[3,41]$.

In Brazil, a study of LBW where only low-income families were included found that the LBW children resided in households with poor environments, fewer resources, and mothers with less education than their average birth 
Table 2 Multivariate logistic analysis of the association of low birthweight with childhood stunting while controlling for several covariates

\begin{tabular}{|c|c|c|c|c|c|c|c|}
\hline Variables & $\begin{array}{l}\text { Model I } \\
\text { COR 95\% (Cl) }\end{array}$ & $\begin{array}{l}\text { Model II } \\
\text { aOR 95\% (Cl) }\end{array}$ & $\begin{array}{l}\text { Model III } \\
\text { aOR 95\% (Cl) }\end{array}$ & $\begin{array}{l}\text { Model IV } \\
\text { aOR 95\% (Cl) }\end{array}$ & $\begin{array}{l}\text { Model V } \\
\text { aOR 95\% (Cl) }\end{array}$ & $\begin{array}{l}\text { Model VI } \\
\text { aOR 95\% (Cl) }\end{array}$ & $\begin{array}{l}\text { Model VII } \\
\text { aOR 95\% (Cl) }\end{array}$ \\
\hline \multicolumn{8}{|l|}{ Birth weight } \\
\hline Low birthweight ${ }^{a}$ & $1.72(1.35-2.20)^{*}$ & $1.63(1.26-2.10)^{*}$ & $1.63(1.26-2.11)^{*}$ & $1.55(1.19-2.01)^{*}$ & $1.55(1.19-2.01)^{*}$ & $1.54(1.18-2.00)^{*}$ & $1.55(1.19-2.01)^{*}$ \\
\hline Normal and above & 1.00 & 1.00 & 1.00 & 1.00 & 1.00 & 1.00 & 1.00 \\
\hline \multicolumn{8}{|l|}{ Sex of the child } \\
\hline Male & & $1.21(1.04-1.41)^{*}$ & $1.21(1.04-1.41)^{*}$ & $1.22(1.05-1.43)^{*}$ & $1.22(1.05-1.43)^{*}$ & $1.23(1.05-1.43)^{*}$ & $1.23(1.05-1.44)^{*}$ \\
\hline Female & & 1.00 & 1.00 & 1.00 & 1.00 & 1.00 & 1.00 \\
\hline \multicolumn{8}{|l|}{ Age } \\
\hline $6-11$ & & $0.56(0.41-0.76)^{*}$ & $0.54(0.39-0.74)^{*}$ & $0.50(0.36-0.69)^{*}$ & $0.49(0.36-0.69)^{*}$ & $0.49(0.35-0.69)^{*}$ & $0.49(0.36-0.69)^{*}$ \\
\hline $12-23$ & & $1.19(0.93-1.51)$ & $1.16(0.90-1.48)$ & $1.08(0.84-1.39)$ & $1.08(0.84-1.39)$ & $1.08(0.84-1.39)$ & $1.08(0.84-1.39)$ \\
\hline $24-35$ & & $1.46(1.14-1.86)^{*}$ & $1.45(1.13-1.86)^{*}$ & $1.39(1.08-1.78)^{*}$ & $1.39(1.08-1.78)^{*}$ & $1.38(1.08-1.77)^{*}$ & $1.39(1.09-1.78)^{*}$ \\
\hline $36-47$ & & $1.54(1.21-1.95)^{*}$ & $1.53(1.21-1.95)^{*}$ & $1.52(1.20-1.93)^{*}$ & $1.52(1.20-1.93)^{*}$ & $1.52(1.20-1.93)^{*}$ & $1.53(1.20-1.94)^{*}$ \\
\hline $48-59$ & & 1.00 & 1.00 & 1.00 & 1.00 & 1.00 & 1.00 \\
\hline \multicolumn{8}{|l|}{ Multiple births } \\
\hline Single births & & $0.49(0.28-0.88)^{*}$ & $0.50(0.28-0.89)^{*}$ & $0.47(0.27-0.81)^{*}$ & $0.47(0.28-0.82)^{*}$ & $0.48(0.28-0.83)^{*}$ & $0.47(0.28-0.81)^{*}$ \\
\hline Twins & & 1.00 & 1.00 & 1.00 & 1.00 & 1.00 & 1.00 \\
\hline \multicolumn{8}{|l|}{ Preceding birth interval } \\
\hline$<24$ & & $1.23(0.99-1.53)$ & $1.23(0.99-1.53)$ & $1.05(0.80-1.39)$ & $1.05(0.80-1.39)$ & $1.05(0.80-1.39)$ & $1.04(0.79-1.37)$ \\
\hline $24-47$ & & $1.14(0.91-1.42)$ & $1.14(0.91-1.42)$ & $0.95(0.74-1.20)$ & $0.94(0.74-1.20)$ & $0.95(0.74-1.20)$ & $0.93(0.73-1.18)$ \\
\hline $48+$ & & 1.00 & 1.00 & 1.00 & 1.00 & 1.00 & 1.00 \\
\hline \multicolumn{8}{|l|}{ Recent diarrhea ${ }^{b}$} \\
\hline No & & & $0.90(0.73-1.11)$ & $0.87(0.70-1.08)$ & $0.87(0.70-1.07)$ & $0.87(0.71-1.08)$ & $0.87(0.70-1.08)$ \\
\hline Yes & & & 1.00 & 1.00 & 1.00 & 1.00 & 1.00 \\
\hline \multicolumn{8}{|l|}{ Recent fever ${ }^{c}$} \\
\hline No & & & $1.05(0.89-1.26)$ & $1.08(0.90-1.29)$ & $1.08(0.90-1.29)$ & $1.07(0.90-1.28)$ & $1.07(0.90-1.28)$ \\
\hline Yes & & & 1.00 & 1.00 & 1.00 & 1.00 & 1.00 \\
\hline \multicolumn{8}{|l|}{ Maternal age } \\
\hline $15-19$ & & & & $0.86(0.56-1.31)$ & $0.86(0.56-1.31)$ & $0.84(0.55-1.29)$ & $0.87(0.57-1.33)$ \\
\hline $20-24$ & & & & $1.15(0.86-1.54)$ & $1.15(0.86-1.53)$ & $1.14(0.85-1.52)$ & $1.16(0.87-1.55)$ \\
\hline $25-29$ & & & & $0.91(0.69-1.21)$ & $0.91(0.69-1.21)$ & $0.90(0.68-1.20)$ & $0.91(0.69-1.20)$ \\
\hline $30-34$ & & & & $0.85(0.63-1.13)$ & $0.85(0.63-1.13)$ & $0.84(0.62-1.12)$ & $0.85(0.63-1.13)$ \\
\hline $35-49$ & & & & 1.00 & 1.00 & 1.00 & 1.00 \\
\hline \multicolumn{8}{|c|}{ Maternal education levels } \\
\hline No education & & & & $1.56(1.13-2.18)^{*}$ & $1.57(1.13-2.17)^{*}$ & $1.58(1.14-2.20)^{*}$ & $1.59(1.15-2.21)^{*}$ \\
\hline Primary & & & & $1.17(0.93-1.46)$ & $1.17(0.93-1.46)$ & $1.17(0.93-1.46)$ & $1.15(0.92-1.44)$ \\
\hline $\begin{array}{l}\text { Secondary and } \\
\text { above }\end{array}$ & & & & 1.00 & 1.00 & 1.00 & 1.00 \\
\hline \multicolumn{8}{|l|}{$\begin{array}{l}\text { Maternal body mass } \\
\text { index }\end{array}$} \\
\hline Underweight & & & & $2.02(1.34-3.04)^{*}$ & $2.03(1.34-3.06)^{*}$ & $2.05(1.36-3.09)^{*}$ & $2.06(1.36-3.10)^{*}$ \\
\hline Optimal weight & & & & $1.46(1.16-1.84)^{*}$ & $1.46(1.16-1.84)^{*}$ & $1.48(1.17-1.86)^{*}$ & $1.47(1.16-1.85)^{*}$ \\
\hline Overweight/obesity & & & & 1.00 & 1.00 & 1.00 & 1.00 \\
\hline \multicolumn{8}{|l|}{ Wealth index } \\
\hline Poorest & & & & $2.28(1.64-3.19)^{*}$ & $2.30(1.64-3.24)^{*}$ & $2.36(1.67-3.33)^{*}$ & $2.04(1.40-2.98)^{*}$ \\
\hline
\end{tabular}


Table 2 Multivariate logistic analysis of the association of low birthweight with childhood stunting while controlling for several covariates (Continued)

\begin{tabular}{|c|c|c|c|c|c|c|c|}
\hline Variables & $\begin{array}{l}\text { Model I } \\
\text { COR 95\% (Cl) }\end{array}$ & $\begin{array}{l}\text { Model II } \\
\text { aOR 95\% (Cl) }\end{array}$ & $\begin{array}{l}\text { Model III } \\
\text { aOR 95\% (Cl) }\end{array}$ & $\begin{array}{l}\text { Model IV } \\
\text { aOR 95\% (Cl) }\end{array}$ & $\begin{array}{l}\text { Model V } \\
\text { aOR 95\% (Cl) }\end{array}$ & $\begin{array}{l}\text { Model VI } \\
\text { aOR 95\% (Cl) }\end{array}$ & $\begin{array}{l}\text { Model VII } \\
\text { aOR 95\% (Cl) }\end{array}$ \\
\hline Poorer & & & & $2.07(1.48-2.90)^{*}$ & $2.08(1.48-2.92)^{*}$ & $2.13(1.50-3.01)^{*}$ & $1.84(1.25-2.69)^{*}$ \\
\hline Middle & & & & $1.73(1.25-2.40)^{*}$ & $1.73(1.24-2.41)^{*}$ & $1.76(1.26-2.46)^{*}$ & $1.55(1.08-2.24)^{*}$ \\
\hline Richer & & & & $1.29(0.91-1.82)$ & $1.29(0.91-1.83)$ & $1.32(0.93-1.87)$ & $1.18(0.81-1.72)$ \\
\hline Richest & & & & 1.00 & 1.00 & 1.00 & 1.00 \\
\hline \multicolumn{8}{|c|}{ No of under-5-year children } \\
\hline$\leq 1$ & & & & $0.71(0.53-0.96)^{*}$ & $0.71(0.53-0.96)^{*}$ & $0.70(0.52-0.95)^{*}$ & $0.70(0.52-0.95)^{*}$ \\
\hline $2-3$ & & & & $0.78(0.59-1.05)$ & $0.78(0.59-1.05)$ & $0.78(0.58-1.05)$ & $0.79(0.59-1.05)$ \\
\hline$\geq 4$ & & & & 1.00 & 1.00 & 1.00 & 1.00 \\
\hline \multicolumn{8}{|c|}{ Amount of media exposure $e^{e}$} \\
\hline 0 & & & & $0.64(0.20-2.03)$ & $0.64(0.20-2.04)$ & $0.66(0.20-2.12)$ & $0.64(0.21-1.99)$ \\
\hline 1 & & & & $0.66(0.21-2.11)$ & $0.67(0.21-2.12)$ & $0.69(0.21-2.20)$ & $0.65(0.21-2.02)$ \\
\hline 2 & & & & $0.53(0.17-1.71)$ & $0.54(0.17-1.72)$ & $0.54(0.17-1.74)$ & $0.53(0.17-1.67)$ \\
\hline 3 & & & & 1.00 & 1.00 & 1.00 & 1.00 \\
\hline \multicolumn{8}{|l|}{ Source of drinking water } \\
\hline Unimproved & & & & & $1.02(0.82-1.28)$ & $1.04(0.83-1.30)$ & $1.03(0.82-1.29)$ \\
\hline Improved $^{f}$ & & & & & 1.00 & 1.00 & 1.00 \\
\hline \multicolumn{8}{|l|}{ Sanitation facility } \\
\hline Unimproved & & & & & $0.95(0.78-1.15)$ & $0.95(0.78-1.16)$ & $0.95(0.78-1.16)$ \\
\hline Improved $^{9}$ & & & & & 1.00 & 1.00 & 1.00 \\
\hline \multicolumn{8}{|l|}{ Place of delivery } \\
\hline Home and other & & & & & & $0.90(0.68-1.20)$ & $0.90(0.68-1.20)$ \\
\hline Hospital/institution ${ }^{\text {h }}$ & & & & & & 1.00 & 1.00 \\
\hline \multicolumn{8}{|c|}{ Perceived Distance to health facility } \\
\hline Perceived problem & & & & & & $1.13(0.96-1.34)$ & $1.15(0.97-1.36)$ \\
\hline $\begin{array}{l}\text { Not perceived } \\
\text { problem }\end{array}$ & & & & & & 1.00 & 1.00 \\
\hline \multicolumn{8}{|l|}{ Place of residence } \\
\hline Urban & & & & & & & $0.70(0.50-0.99)^{*}$ \\
\hline Rural & & & & & & & 1.00 \\
\hline \multicolumn{8}{|l|}{ Geographical region } \\
\hline Northern & & & & & & & $1.07(0.85-1.36)$ \\
\hline Central & & & & & & & $1.18(0.98-1.42)$ \\
\hline Southern & & & & & & & 1.00 \\
\hline
\end{tabular}

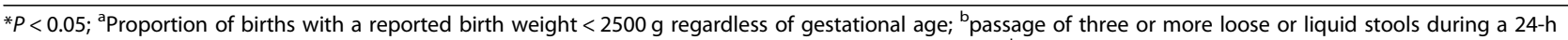
period; ' self-reports by mothers about symptoms that had occurred within 2 weeks prior to the survey; ${ }^{d}$ weight in kilograms divided by the square of his height in

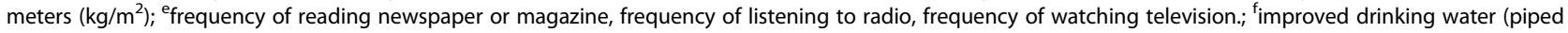
water into dwelling, piped water to yard/plot, public tap or standpipe, tubewell or borehole, protected dug well, protected spring and rainwater); ${ }^{\text {improved }}$ sanitation (flush toilet, piped sewer system, septic tank, flush/pour flush to pit latrine, ventilated improved pit latrine, pit latrine with slab, and composting toilet); h government hospital, government health center, government health post/outreach, other public sector, private hospital/clinic, CHAM/MISSION hospital, CHAM/ MISSION health Center, BLM, other private medical sector

weights counterparts [42]. Prior researchers have also suggested that children born with a LBW are at increased risk for neurological aberrations and delayed growth and development in their early years [43]. Additionally, the relationship between LBW and childhood undernutrition may be mediated by increased morbidity (infection) in LBW children [42, 44]. It is well documented that malnutrition is the major cause of the immunodeficiency thus increasing susceptibility to infections whilst infections exacerbate malnutrition by reducing appetite, reducing absorption, 
Table 3 Multivariate logistic analysis of the association of low birthweight with childhood underweight while controlling for several covariates

\begin{tabular}{|c|c|c|c|c|c|c|c|}
\hline Variables & $\begin{array}{l}\text { Model I } \\
\text { COR 95\% (Cl) }\end{array}$ & $\begin{array}{l}\text { Model II } \\
\text { aOR 95\% (Cl) }\end{array}$ & $\begin{array}{l}\text { Model III } \\
\text { aOR 95\% (Cl) }\end{array}$ & $\begin{array}{l}\text { Model IV } \\
\text { aOR 95\% (Cl) }\end{array}$ & $\begin{array}{l}\text { Model V } \\
\text { aOR 95\% (Cl) }\end{array}$ & $\begin{array}{l}\text { Model VI } \\
\text { aOR 95\% (Cl) }\end{array}$ & $\begin{array}{l}\text { Model VII } \\
\text { aOR 95\% (Cl) }\end{array}$ \\
\hline \multicolumn{8}{|l|}{ Birth weight } \\
\hline Low birthweight ${ }^{a}$ & $2.30(1.68-3.14)^{*}$ & $2.28(1.65-3.14)^{*}$ & $2.29(1.65-3.16)^{*}$ & $2.15(1.56-2.99)^{*}$ & $2.15(1.55-2.98)^{*}$ & $2.15(1.56-2.99)^{*}$ & $2.16(1.56-2.99)^{*}$ \\
\hline Normal and above & 1.00 & 1.00 & 1.00 & 1.00 & 1.00 & 1.00 & 1.00 \\
\hline \multicolumn{8}{|l|}{ Sex of the child } \\
\hline Male & & $1.23(0.99-1.52)$ & $1.22(0.98-1.52)$ & $1.21(0.97-1.51)$ & $1.22(0.98-1.53)$ & $1.22(0.98-1.53)$ & $1.22(0.98-1.53)$ \\
\hline Female & & 1.00 & 1.00 & 1.00 & 1.00 & 1.00 & 1.00 \\
\hline \multicolumn{8}{|l|}{ Age } \\
\hline $6-11$ & & $0.79(0.52-1.19)$ & $0.74(0.48-1.16)$ & $0.70(0.44-1.11)$ & $0.69(0.43-1.10)$ & $0.68(0.43-1.09)$ & $0.68(0.43-1.10)$ \\
\hline $12-23$ & & $0.98(0.69-1.41)$ & $0.93(0.65-1.34)$ & $0.88(0.61-1.28)$ & $0.88(0.61-1.27)$ & $0.88(0.61-1.28)$ & $0.88(0.61-1.28)$ \\
\hline $24-35$ & & $0.98(0.68-1.42)$ & $0.96(0.66-1.39)$ & $0.88(0.62-1.29)$ & $0.88(0.60-1.28)$ & $0.88(0.61-1.29)$ & $0.88(0.60-1.28)$ \\
\hline $36-47$ & & $1.24(0.87-1.78)$ & $1.23(0.86-1.77)$ & $1.19(0.83-1.72)$ & $1.20(0.83-1.73)$ & $1.20(0.83-1.72)$ & $1.19(0.83-1.72)$ \\
\hline $48-59$ & & 1.00 & 1.00 & 1.00 & 1.00 & 1.00 & 1.00 \\
\hline \multicolumn{8}{|l|}{ Multiple births } \\
\hline Single births & & $0.88(0.41-1.90)$ & $0.89(0.41-1.92)$ & $0.85(0.40-1.83)$ & $0.89(0.42-1.90)$ & $0.89(0.42-1.90)$ & $0.88(0.41-1.90)$ \\
\hline Twins & & 1.00 & 1.00 & 1.00 & 1.00 & 1.00 & 1.00 \\
\hline \multicolumn{8}{|l|}{ Preceding birth interval } \\
\hline$<24$ & & $1.20(0.87-1.65)$ & $1.20(0.87-1.64)$ & $1.11(0.73-1.67)$ & $1.10(0.73-1.66)$ & $1.10(0.73-1.66)$ & $1.11(0.74-1.66)$ \\
\hline $24-47$ & & $1.15(0.85-1.57)$ & $1.15(0.85-1.57)$ & $1.06(0.75-1.51)$ & $1.06(0.74-1.50)$ & $1.05(0.74-1.50)$ & $1.06(0.75-1.50)$ \\
\hline $48+$ & & 1.00 & 1.00 & 1.00 & 1.00 & 1.00 & 1.00 \\
\hline \multicolumn{8}{|l|}{ Recent diarrhea ${ }^{\mathrm{b}}$} \\
\hline No & & & $0.86(0.63-1.16)$ & $0.84(0.61-1.14)$ & $0.83(0.61-1.13)$ & $0.83(0.61-1.13)$ & $0.83(0.61-1.13)$ \\
\hline Yes & & & 1.00 & 1.00 & 1.00 & 1.00 & 1.00 \\
\hline \multicolumn{8}{|l|}{ Recent fever ${ }^{c}$} \\
\hline No & & & $1.00(0.78-1.28)$ & $0.99(0.77-1.29)$ & $0.99(0.76-1.29)$ & $0.99(0.76-1.29)$ & $0.99(0.76-1.29)$ \\
\hline Yes & & & 1.00 & 1.00 & 1.00 & 1.00 & 1.00 \\
\hline \multicolumn{8}{|l|}{ Maternal age } \\
\hline $15-19$ & & & & $0.64(0.33-1.26)$ & $0.62(0.32-1.22)$ & $0.62(0.31-1.22)$ & $0.61(0.31-1.21)$ \\
\hline $20-24$ & & & & $1.01(0.68-1.52)$ & $1.00(0.67-1.49)$ & $1.00(0.66-1.49)$ & $0.98(0.66-1.47)$ \\
\hline $25-29$ & & & & $0.74(0.49-1.13)$ & $0.73(0.48-1.11)$ & $0.73(0.48-1.12)$ & $0.73(0.48-1.11)$ \\
\hline $30-34$ & & & & $0.82(0.54-1.27)$ & $0.82(0.53-1.25)$ & $0.82(0.53-1.27)$ & $0.82(0.53-1.26)$ \\
\hline $35-49$ & & & & 1.00 & 1.00 & 1.00 & 1.00 \\
\hline \multicolumn{8}{|l|}{ Maternal education levels } \\
\hline No education & & & & $1.16(0.73-1.84)$ & $1.13(0.71-1.80)$ & $1.13(0.71-1.80)$ & $1.10(0.70-1.74)$ \\
\hline Primary & & & & $0.98(0.66-1.45)$ & $0.97(0.65-1.45)$ & $0.96(0.65-1.45)$ & $0.95(0.64-1.41)$ \\
\hline Secondary and above & & & & 1.00 & 1.00 & 1.00 & 1.00 \\
\hline \multicolumn{8}{|c|}{ Maternal body mass index ${ }^{d}$} \\
\hline Underweight & & & & $3.40(1.93-5.97)^{*}$ & $3.55(2.03-6.20)^{*}$ & $3.52(2.01-6.14)^{*}$ & $3.52(2.02-6.13)^{*}$ \\
\hline Optimal weight & & & & $1.54(1.03-2.32)^{*}$ & $1.57(1.05-2.34)^{*}$ & $1.57(1.05-2.35)^{*}$ & $1.56(1.04-2.34)^{*}$ \\
\hline Overweight/obesity & & & & 1.00 & 1.00 & 1.00 & 1.00 \\
\hline \multicolumn{8}{|l|}{ Wealth index } \\
\hline Poorest & & & & $1.74(1.00-3.03)^{*}$ & $1.76(1.01-3.07)^{*}$ & $1.77(1.01-3.14)^{*}$ & $1.76(0.95-3.24)$ \\
\hline Poorer & & & & $1.47(0.84-2.55)$ & $1.46(0.83-2.56)$ & $1.48(0.83-2.63)$ & $1.46(0.79-2.71)$ \\
\hline Middle & & & & $1.37(0.76-2.47)$ & $1.35(0.75-2.45)$ & $1.36(0.75-2.48)$ & $1.34(0.70-2.55)$ \\
\hline Richer & & & & $1.17(0.64-2.12)$ & $1.17(0.65-2.14)$ & $1.19(0.65-2.18)$ & $1.17(0.62-2.20)$ \\
\hline
\end{tabular}


Table 3 Multivariate logistic analysis of the association of low birthweight with childhood underweight while controlling for several covariates (Continued)

\begin{tabular}{|c|c|c|c|c|c|c|c|}
\hline Variables & $\begin{array}{l}\text { Model I } \\
\text { COR 95\% (CI) }\end{array}$ & $\begin{array}{l}\text { Model II } \\
\text { aOR 95\% (Cl) }\end{array}$ & $\begin{array}{l}\text { Model III } \\
\text { aOR 95\% (Cl) }\end{array}$ & $\begin{array}{l}\text { Model IV } \\
\text { aOR 95\% (Cl) }\end{array}$ & $\begin{array}{l}\text { Model V } \\
\text { aOR 95\% (Cl) }\end{array}$ & $\begin{array}{l}\text { Model VI } \\
\text { aOR 95\% (Cl) }\end{array}$ & $\begin{array}{l}\text { Model VII } \\
\text { aOR 95\% (Cl) }\end{array}$ \\
\hline Richest & & & & 1.00 & 1.00 & 1.00 & 1.00 \\
\hline \multicolumn{8}{|l|}{ No of under-5-year children } \\
\hline$\leq 1$ & & & & $0.57(0.38-0.91)^{*}$ & $0.58(0.38-0.90)^{*}$ & $0.59(0.38-0.90)^{*}$ & $0.59(0.38-0.90)^{*}$ \\
\hline $2-3$ & & & & $0.51(0.34-0.77)^{*}$ & $0.51(0.34-0.76)^{*}$ & $0.51(0.34-0.76)^{*}$ & $0.51(0.34-0.76)^{*}$ \\
\hline$\geq 4$ & & & & 1.00 & 1.00 & 1.00 & 1.00 \\
\hline \multicolumn{8}{|c|}{ Amount of media exposure ${ }^{e}$} \\
\hline 0 & & & & $3.02(0.81-11.27)$ & $3.08(0.82-11.58)$ & $3.14(0.84-11.81)$ & $3.17(0.84-11.92)$ \\
\hline 1 & & & & $2.73(0.72-10.30)$ & $2.76(0.73-10.51)$ & $2.81(0.74-10.69)$ & $2.89(0.76-11.00)$ \\
\hline 2 & & & & $1.39(0.33-5.08)$ & $1.43(0.34-6.07)$ & $1.45(0.35-6.01)$ & $1.47(0.35-6.18)$ \\
\hline 3 & & & & 1.00 & 1.00 & 1.00 & 1.00 \\
\hline \multicolumn{8}{|l|}{ Source of drinking water } \\
\hline Unimproved & & & & & $1.31(0.97-1.77)$ & $1.31(0.97-1.77)$ & $1.31(0.97-1.78)$ \\
\hline Improved $^{f}$ & & & & & 1.00 & 1.00 & 1.00 \\
\hline \multicolumn{8}{|l|}{ Sanitation facility } \\
\hline Unimproved & & & & & $0.77(0.56-1.05)$ & $0.77(0.56-1.05)$ & $0.76(0.55-1.04)$ \\
\hline Improved $^{g}$ & & & & & 1.00 & 1.00 & 1.00 \\
\hline \multicolumn{8}{|l|}{ Place of delivery } \\
\hline Home and other & & & & & & $1.12(0.76-1.66)$ & $1.13(0.77-1.67)$ \\
\hline Hospital/institution ${ }^{\text {h }}$ & & & & & & 1.00 & 1.00 \\
\hline \multicolumn{8}{|c|}{ Perceived distance to health facility } \\
\hline Perceived problem & & & & & & $1.78(0.84-1.39)$ & $1.08(0.84-1.39)$ \\
\hline Not perceived problem & & & & & & 1.00 & 1.00 \\
\hline \multicolumn{8}{|l|}{ Place of residence } \\
\hline Urban & & & & & & & $0.94(0.51-1.72)$ \\
\hline Rural & & & & & & & 1.00 \\
\hline \multicolumn{8}{|l|}{ Geographical region } \\
\hline Northern & & & & & & & $0.88(0.60-1.30)$ \\
\hline Central & & & & & & & $0.87(0.68-1.12)$ \\
\hline Southern & & & & & & & 1.00 \\
\hline
\end{tabular}

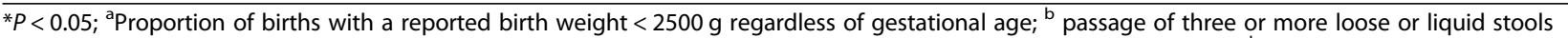
during a 24-h period; ' self-reports by mothers about symptoms that had occurred within 2 weeks prior to the survey; ${ }^{d}$ weight in kilograms divided by

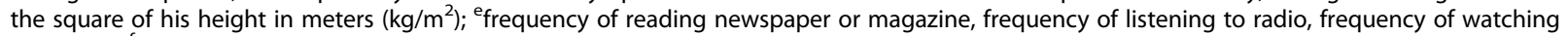
television.; fimproved drinking water (piped water into dwelling, piped water to yard/plot, public tap or standpipe, tubewell or borehole, protected dug well, protected spring and rainwater); ${ }^{9}$ improved sanitation (flush toilet, piped sewer system, septic tank, flush/pour flush to pit latrine, ventilated improved pit latrine, pit latrine with slab, and composting toilet); ${ }^{\mathrm{h}}$ government hospital, government health center, government health post/outreach, other public sector, private hospital/clinic, CHAM/MISSION hospital, CHAM/MISSION health Center, BLM, other private medical sector

inducing catabolism, and increasing excretion due to vomiting and diarrhea $[45,46]$. Previously it has been reported that the very-low-birth-weight infants are at high risk for developing an infection during the antenatal, prenatal, and postnatal periods [47]. Hence, all of these conditions can negatively affect child growth patterns.

\section{Strengths and weakness}

The strength of the present study is the use of the nationally representative dataset which means the results can be generalized at Malawian setting. However, the potential limitations are (1) the use of cross-sectional study design, thus cannot permit us to draw causal inferences and (2) the use of secondary analysis did not permit the inclusion of relevant factors to control for poor pregnancy conditions.

\section{Policy implication}

This study is one of its kind to investigate the independent association of birth weight with childhood undernutrition in Malawi. In particular, the risk of growth and 
Table 4 Multivariate logistic analysis of the association of low birthweight with childhood wasted while controlling for several covariates

\begin{tabular}{|c|c|c|c|c|c|c|c|}
\hline Variables & $\begin{array}{l}\text { Model I } \\
\text { COR 95\% (Cl) }\end{array}$ & $\begin{array}{l}\text { Model II } \\
\text { aOR 95\% (Cl) }\end{array}$ & $\begin{array}{l}\text { Model III } \\
\text { aOR 95\% (Cl) }\end{array}$ & $\begin{array}{l}\text { Model IV } \\
\text { aOR 95\% (Cl) }\end{array}$ & $\begin{array}{l}\text { Model V } \\
\text { aOR 95\% (Cl) }\end{array}$ & $\begin{array}{l}\text { Model VI } \\
\text { aOR 95\% (Cl) }\end{array}$ & $\begin{array}{l}\text { Model VII } \\
\text { aOR 95\% (Cl) }\end{array}$ \\
\hline \multicolumn{8}{|l|}{ Birth weight } \\
\hline Low birthweight ${ }^{a}$ & $2.42(1.38-4.25)^{*}$ & $2.63(1.48-4.67)^{*}$ & $2.63(1.48-4.69)^{*}$ & $2.54(1.41-4.56)^{*}$ & $2.53(1.41-4.57)^{*}$ & $2.56(1.42-4.63)^{*}$ & $2.53(1.40-4.57)^{*}$ \\
\hline Normal and above & 1.00 & 1.00 & 1.00 & 1.00 & 1.00 & 1.00 & 1.00 \\
\hline \multicolumn{8}{|l|}{ Sex of the child } \\
\hline Male & & $1.52(0.95-2.45)$ & $1.49(0.93-2.39)$ & $1.53(0.94-2.52)$ & $1.56(0.95-2.56)$ & $1.56(0.95-2.57)$ & $1.57(0.95-2.59)$ \\
\hline Female & & 1.00 & 1.00 & 1.00 & 1.00 & 1.00 & 1.00 \\
\hline \multicolumn{8}{|l|}{ Age } \\
\hline $6-11$ & & $1.94(0.87-4.37)$ & $1.46(0.65-3.26)$ & $1.18(0.50-2.83)$ & $1.14(0.48-2.75)$ & $1.14(0.47-2.74)$ & $1.07(0.43-2.62)$ \\
\hline $12-23$ & & $1.93(0.89-4.18)$ & $1.43(0.66-3.11)$ & $1.27(0.56-2.93)$ & $1.27(0.55-2.90)$ & $1.27(0.55-2.91)$ & $1.25(0.55-2.88)$ \\
\hline $24-35$ & & $1.15(0.54-2.47)$ & $0.96(0.45-2.07)$ & $0.94(0.42-2.07)$ & $0.93(0.42-2.07)$ & $0.92(0.41-2.06)$ & $0.91(0.41-2.03)$ \\
\hline $36-47$ & & $1.07(0.47-2.43)$ & $0.99(0.43-2.25)$ & $0.99(0.43-2.32)$ & $0.99(0.42-2.32)$ & $0.98(0.42-2.31)$ & $0.95(0.41-2.23)$ \\
\hline $48-59$ & & 1.00 & 1.00 & 1.00 & 1.00 & 1.00 & 1.00 \\
\hline \multicolumn{8}{|l|}{ Multiple births } \\
\hline Single births & & $9.62(2.15-43.0)^{*}$ & $9.43(2.07-43.0)^{*}$ & $12.8(2.59-63.1)^{*}$ & $13.5(2.73-66.4)^{*}$ & $13.0(2.67-63.6)^{*}$ & $13.2(2.69-64.4)^{*}$ \\
\hline Twins & & 1.00 & 1.00 & 1.00 & 1.00 & 1.00 & 1.00 \\
\hline \multicolumn{8}{|l|}{ Preceding birth interval } \\
\hline$<24$ & & $1.44(0.81-2.60)$ & $1.44(0.81-2.57)$ & $1.04(0.50-2.17)$ & $1.02(0.49-2.12)$ & $1.02(0.49-2.12)$ & $1.08(0.51-2.28)$ \\
\hline $24-47$ & & $1.07(0.58-1.94)$ & $1.07(0.58-1.96)$ & $0.87(0.41-1.86)$ & $0.85(0.40-1.82)$ & $0.85(0.40-1.81)$ & $0.91(0.42-1.96)$ \\
\hline $48+$ & & 1.00 & 1.00 & 1.00 & 1.00 & 1.00 & 1.00 \\
\hline \multicolumn{8}{|l|}{ Recent diarrhea ${ }^{\mathrm{b}}$} \\
\hline No & & & $0.58(0.37-0.93)^{*}$ & $0.59(0.37-0.96)^{*}$ & $0.59(0.36-0.95)^{*}$ & $0.59(0.37-0.95)^{*}$ & $0.59(0.36-0.97)^{*}$ \\
\hline Yes & & & 1.00 & 1.00 & 1.00 & 1.00 & 1.00 \\
\hline \multicolumn{8}{|l|}{ Recent fever ${ }^{c}$} \\
\hline No & & & $0.51(0.32-0.82)^{*}$ & $0.47(0.29-0.78)^{*}$ & $0.48(0.29-0.78)^{*}$ & $0.48(0.29-0.79)^{*}$ & $0.48(0.29-0.80)^{*}$ \\
\hline Yes & & & 1.00 & 1.00 & 1.00 & 1.00 & 1.00 \\
\hline \multicolumn{8}{|l|}{ Maternal age } \\
\hline $15-19$ & & & & $1.24(0.41-3.72)$ & $1.21(0.40-3.59)$ & $1.24(0.41-3.71)$ & $1.11(0.37-3.36)$ \\
\hline $20-24$ & & & & $0.90(0.42-1.93)$ & $0.90(0.42-1.90)$ & $0.91(0.43-1.94)$ & $0.83(0.38-1.78)$ \\
\hline $25-29$ & & & & $0.94(0.45-1.99)$ & $0.93(0.44-1.95)$ & $0.94(0.44-1.99)$ & $0.92(0.43-1.97)$ \\
\hline $30-34$ & & & & $0.55(0.24-1.28)$ & $0.54(0.23-1.25)$ & $0.55(0.23-1.28)$ & $0.52(0.22-1.22)$ \\
\hline $35-49$ & & & & 1.00 & 1.00 & 1.00 & 1.00 \\
\hline \multicolumn{8}{|c|}{ Maternal education levels } \\
\hline No education & & & & $0.70(0.27-1.78)$ & $0.66(0.26-1.72)$ & $0.66(0.26-1.72)$ & $0.65(0.23-1.82)$ \\
\hline Primary & & & & $0.80(0.40-1.59)$ & $0.79(0.39-1.55)$ & $0.80(0.39-1.61)$ & $0.85(0.39-1.83)$ \\
\hline $\begin{array}{l}\text { Secondary and } \\
\text { above }\end{array}$ & & & & 1.00 & 1.00 & 1.00 & 1.00 \\
\hline \multicolumn{8}{|c|}{ Maternal body mass index ${ }^{d}$} \\
\hline Underweight & & & & $5.00(1.64-15.2)^{*}$ & $5.28(1.68-16.5)^{*}$ & $5.21(1.67-16.2)^{*}$ & $5.45(1.71-17.3)^{*}$ \\
\hline Optimal weight & & & & $2.26(0.92-5.54)$ & $2.30(0.93-5.70)$ & $2.25(0.91-5.61)$ & $2.40(0.97-5.99)$ \\
\hline Overweight/obesity & & & & 1.00 & 1.00 & 1.00 & 1.00 \\
\hline \multicolumn{8}{|l|}{ Wealth index } \\
\hline Poorest & & & & $0.64(0.25-1.67)$ & $0.65(0.25-1.66)$ & $0.63(0.24-1.68)$ & $0.91(0.39-2.20)$ \\
\hline Poorer & & & & $0.45(0.18-1.80)$ & $0.45(0.18-1.76)$ & $0.43(0.17-1.12)$ & $0.63(0.27-1.47)$ \\
\hline
\end{tabular}


Table 4 Multivariate logistic analysis of the association of low birthweight with childhood wasted while controlling for several covariates (Continued)

\begin{tabular}{|c|c|c|c|c|c|c|c|}
\hline Variables & $\begin{array}{l}\text { Model I } \\
\text { COR 95\% (Cl) }\end{array}$ & $\begin{array}{l}\text { Model II } \\
\text { aOR 95\% (Cl) }\end{array}$ & $\begin{array}{l}\text { Model III } \\
\text { aOR 95\% (Cl) }\end{array}$ & $\begin{array}{l}\text { Model IV } \\
\text { aOR 95\% (Cl) }\end{array}$ & $\begin{array}{l}\text { Model V } \\
\text { aOR 95\% (Cl) }\end{array}$ & $\begin{array}{l}\text { Model VI } \\
\text { aOR 95\% (Cl) }\end{array}$ & $\begin{array}{l}\text { Model VII } \\
\text { aOR 95\% (Cl) }\end{array}$ \\
\hline Middle & & & & $0.62(0.23-1.66)$ & $0.61(0.23-1.66)$ & $0.60(0.22-1.67)$ & $0.86(0.35-2.08)$ \\
\hline Richer & & & & $0.65(0.24-1.75)$ & $0.66(0.25-1.75)$ & $0.64(0.23-1.78)$ & $0.85(0.36-2.04)$ \\
\hline Richest & & & & 1.00 & 1.00 & 1.00 & 1.00 \\
\hline \multicolumn{8}{|c|}{ No of under-5-year children } \\
\hline$\leq 1$ & & & & $0.40(0.18-0.88)^{*}$ & $0.39(0.18-0.86)^{*}$ & $0.39(0.18-0.87)^{*}$ & $0.40(0.18-0.61)^{*}$ \\
\hline $2-3$ & & & & $0.44(0.21-0.96)^{*}$ & $0.44(0.21-0.94)^{*}$ & $0.44(0.21-0.94)^{*}$ & $0.44(0.21-0.94)^{*}$ \\
\hline$\geq 4$ & & & & 1.00 & 1.00 & 1.00 & 1.00 \\
\hline \multicolumn{8}{|c|}{ Amount of media exposure } \\
\hline 0 & & & & $1.15(0.16-8.05)$ & $1.17(0.17-8.25)$ & $1.08(0.15-7.58)$ & $1.11(0.15-7.58)$ \\
\hline 1 & & & & $0.76(0.11-5.23)$ & $0.78(0.11-5.34)$ & $0.71(0.10-4.91)$ & $0.76(0.11-5.24)$ \\
\hline 2 & & & & $0.55(0.06-4.94)$ & $0.56(0.06-5.06)$ & $0.53(0.06-4.89)$ & $0.51(0.06-4.54)$ \\
\hline 3 & & & & 1.00 & 1.00 & 1.00 & 1.00 \\
\hline \multicolumn{8}{|l|}{ Source of drinking water } \\
\hline Unimproved & & & & & $1.40(0.76-2.56)$ & $1.38(0.76-2.53)$ & $1.44(0.79-2.65)$ \\
\hline Improved $^{f}$ & & & & & 1.00 & 1.00 & 1.00 \\
\hline \multicolumn{8}{|l|}{ Sanitation facility } \\
\hline Unimproved & & & & & $0.72(0.42-1.25)$ & $0.73(0.42-1.25)$ & $0.72(0.42-1.24)$ \\
\hline Improved ${ }^{g}$ & & & & & 1.00 & 1.00 & 1.00 \\
\hline \multicolumn{8}{|l|}{ Place of delivery } \\
\hline Home and other & & & & & & $1.08(0.53-2.23)$ & $1.06(0.51-2.20)$ \\
\hline Hospital/institution ${ }^{\text {h }}$ & & & & & & 1.00 & 1.00 \\
\hline \multicolumn{8}{|c|}{ Distance to health facility } \\
\hline Perceived problem & & & & & & $0.83(0.50-1.39)$ & $0.81(0.48-1.36)$ \\
\hline $\begin{array}{l}\text { Not perceived } \\
\text { problem }\end{array}$ & & & & & & 1.00 & 1.00 \\
\hline \multicolumn{8}{|l|}{ Place of residence } \\
\hline Urban & & & & & & & $2.21(1.01-4.84)^{*}$ \\
\hline Rural & & & & & & & 1.00 \\
\hline \multicolumn{8}{|l|}{ Geographical region } \\
\hline Northern & & & & & & & $0.65(0.30-1.41)$ \\
\hline Central & & & & & & & $0.70(0.40-1.22)$ \\
\hline Southern & & & & & & & 1.00 \\
\hline
\end{tabular}

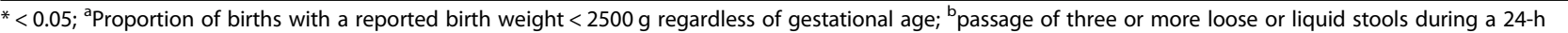
period; ' cself-reports by mothers about symptoms that had occurred within 2 weeks prior to the survey; ${ }^{d}$ weight in kilograms divided by the square of his height in meters $\left(\mathrm{kg} / \mathrm{m}^{2}\right)$; frequency of reading newspaper or magazine, frequency of listening to radio, frequency of watching television.; ${ }^{f_{i m p r o v e d}}$ drinking water (piped water into dwelling, piped water to yard/plot, public tap or standpipe, tubewell or borehole, protected dug well, protected spring and rainwater); ${ }^{9}$ improved sanitation (flush toilet, piped sewer system, septic tank, flush/pour flush to pit latrine, ventilated improved pit latrine, pit latrine with slab, and composting toilet);

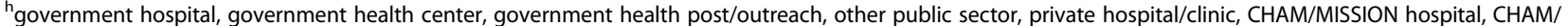
MISSION health Center, BLM, other private medical sector

development impairment in the early childhood years were found to be higher in children with LBW than in those with normal birth weights even after controlling for other known risk factors for childhood undernutrition in models. The finding of the current study seems to be an alarm call for all policymakers involved in the development of childhood nutrition policies in Malawi. Thus, the nutrition events throughout the life cycle should not be neglected. Pregnant women should be encouraged to follow good health habits such adequate intake of good nutritious diets, preconception weight should be monitored, they should be discouraged from smoking, and they should be treated for anemia, malaria, and any intrauterine infection so as to minimize LBW deliveries. 


\section{Conclusion}

The current study has revealed that the prevalence of undernutrition remains unacceptably high in Malawi, despite numerous interventions that are being implemented. The growth and development of the child are significantly predisposed by several factors. In this study, LBW babies were strongly associated with an increased risk of undernutrition. Therefore, in addition to breastfeeding, complementary feeding practices, disease prevention and case management, improved household environments, maternal education, parental behavior that previous studies suggested, interventions that aim at improving the growth and development of preschoolaged children should begin right in utero in order to avoid IUGR which result into LBW.

\section{Additional files}

Additional file 1: Table S1. Results of multicollinearity testing for undernutrition in Malawi (DOC 43 kb)

Additional file 2: Figure S1. Fit Diagnostics for Childhood Undernutriton in Malawi (a) Stunting, (b) Underweight, (c) Wasted (JPG 1607 kb)

\section{Abbreviations \\ AOR: Adjusted Odds Ratio; CDC: Centers for Disease Control; CFR: Code of Federal Regulations; IRB: Institutional Review Board; IUGR: Intrauterine Growth Retardation; LBW: Low Birth Weight; MDHS: Malawi Demographic and Health Survey; NC: New York City; NHSRC: National Health Sciences Research Committee; PROC: Procedure; SAS: Statistical Analysis Software; SD: Standard Deviations; UNICEF: United Nations Children's Fund; USA: United States of America; WHO: World Health Organization}

\section{Acknowledgments}

The author wish expresses gratefulness to the National Statistical Office (NSO) of Malawi for data collection. The authors are also grateful to the MEASURE DHS for giving us access to the population-based dataset through their archives.

\section{Authors' contributions}

PAMN contributed to the conception and design of the study. PAMN acquired the data, conducted analysis and interpretation of the results. PAMN drafted the first article and revised it critically for important intellectual content. PAMN reviewed and approved the final version of the manuscript.

\section{Funding}

This research received no grant from any funding agency in the public, commercial or not-for-profit sectors.

\section{Availability of data and materials}

The datasets generated and/or analyzed during the current study are available in the DHS Program repository, http://dhsprogram.com/data/available-datasets.cfm.

\section{Ethics approval and consent to participate}

This study was conducted according to the guidelines laid down in the Declaration of Helsinki and all procedures involving human subjects were approved by the Malawi National Health Science Research Committee and the Institutional Review Board (IRB) of ICF Macro, and the Centers for Disease Control (CDC) in Atlanta. Informed consent was obtained at the beginning of each interview and the authors sought permission from the DHS program for the use of the data.

\section{Consent for publication}

Not Applicable.

\section{Competing interests}

The author declares that he has no competing interests.

Received: 3 April 2019 Accepted: 21 August 2019

Published online: 02 September 2019

\section{References}

1. Müller $\mathrm{O}$, Krawinkel M. Malnutrition and health in developing countries. CMAJ. 2005:173(3):279-86.

2. Pravana NK, Piryani S, Chaurasiya SP, Kawan R, Thapa RK, Shrestha S. Determinants of severe acute malnutrition among children under 5 years of age in Nepal: a community-based case-control study. BMJ Open. 2017;7(8):e017084.

3. Ntenda PA, Chuang YC. Analysis of individual-level and community-level effects on childhood undernutrition in Malawi. Pediatr Neonatol. 2018;59(4):380-9.

4. World Health Organization (WHO). Malnutrition. Geneva: WHO; 2018. Cited 2018 Aug 31. Available from: http://www.who.int/news-room/fact-sheets/ detail/malnutrition

5. Kramer CV, Allen S. Malnutrition in developing countries. Paediatr Child Health. 2015;25(9):422-7.

6. United Nations Children's Fund (UNICEF). UNICEF conceptual framework: Immediate Causes of Undernutrition; 2008. http://www.unicef.org/nutrition/ training/2.5/5.html. Accessed 26 Apr 2016

7. United Nations Children's Fund (UNICEF). Unicef's approach to scaling up nutrition, vol. 40: Program Div; 2015. https://www.unicef.org/nutrition/files/ Unicef_Nutrition_Strategy.pdf. Accessed 26 Apr 2016.

8. Brown JE. Nutrition through the life cycle. Cengage Learning; 2016.

9. Uauy R. Nutrition throughout the life cycle. Eur J Clin Nutr. 1999:53:S8.

10. ACC/SCN. Fourth Report on the World Nutrition Situation. Geneva: ACC/SCN in collaboration with IFPRI. 2000.

11. Virtual Medical Centre (VMC). Under-Nutrition Before and During Pregnancy. Virtue Med Cent. 2010:1-4. http://www.myvmc.com/pregnancy/undernutrition-before-and-during-pregnancy/\#C9 Accessed 26 Apr 2016.

12. United Nations Children's Fund (UNICEF). Low birthweight: UNICEF; 2014. https://data.unicef.org/topic/nutrition/low-birthweight/ Accessed 1 Sept 2018

13. Agbor VN, Ditah C, Tochie JN, Njim T. Low birthweight in rural Cameroon: an analysis of a cut-off value. BMC Pregnancy Childbirth. 2018;18(1):30.

14. National Statistical Office (NSO) [Malawi] and ICF. Malawi Demographic and Health Survey 2015-16. Zomba and Rockville: NSO and ICF; 2017.

15. World Health Organization (WHO). Low Birthweight. 2001. https://www. unicef.org/specialsession/about/sgreport-pdf/15_LowBirthweight_D7341 Insert_English.pdf Accessed 1 Sept 2018.

16. Ramakrishnan U. Nutrition and low birth weight: from research to practice. Am J Clin Nutr. 2004;79(1):17-21.

17. Ministry of Health and Population Malawi (MoHP). Infant and young child nutrition policy and guidelines; 2003. p. 1-66.

18. National Statistical Office (NSO) [Malawi]. Malawi demographic and health survey. Calverton: NSO and ORC Macro; 2004. p. 2005.

19. National Statistical Office (NSO), ICF Macro. Malawi demographic and health survey. Zomba and Calverton: NSO and ICF Macro; 2010. p. 2011.

20. Hong R, Ruiz-Beltran M. Low birth weight as a risk factor for infant mortality in Egypt. East Mediterr Health J. 2008;14(5):992-1002.

21. Kusuda S, Fujimura M, Uchiyama A, Totsu S, Matsunami K. Trends in morbidity and mortality among very-low-birth-weight infants from 2003 to 2008 in Japan. Pediatr Res. 2012;72(5):531.

22. O'Leary M, Edmond K, Floyd S, Newton S, Thomas G, Thomas SL. A cohort study of low birth weight and health outcomes in the first year of life, Ghana. Bull World Health Organ. 2017:95(8):574.

23. Aryastami NK, Shankar A, Kusumawardani N, Besral B, Jahari AB, Achadi E. Low birth weight was the most dominant predictor associated with stunting among children aged 12-23 months in Indonesia. BMC Nutrition. 2017;3(1):16.

24. Rahman A, Chowdhury S. Determinants of chronic malnutrition among preschool children in Bangladesh. J Biosoc Sci. 2007;39(2):161-73.

25. Rayhan MI, Khan MS. Factors causing malnutrition among under five children in Bangladesh. Pak J Nutr. 2006;5(6):558-62.

26. De Onis M. The new WHO child growth standards. Paediatr Croat Suppl. 2008;52(SUPP.1):13-7 http://hpps.kbsplit.hr/hpps-2008/pdf/dok03.pdf Accessed 6 Sept 2018.

27. de Onis M, Branca F. Childhood stunting: a global perspective. Matern Child Nutr. 2016;12:12-26.

28. de Onis M, Monika B. Global database on child growth and malnutrition, vol. 74. Geneva: WHO; 1997. 
29. Weise A. WHA global nutrition targets 2025: low birth weight policy brief: WHO Publ; 2012. p. 1-7. http://www.who.int/nutrition/topics/globaltargets_ stunting_policybrief.pdf. Accessed 6 Sept 2018.

30. United Nations Children's Fund and World Health Organization. Low birthweight: country, regional and global estimates. New York: UNICEF; 2004.

31. Chowdhury MR, Rahman MS, Khan MM, Mondal MN, Rahman MM, Billah B. Risk factors for child malnutrition in Bangladesh: a multilevel analysis of a nationwide population-based survey. J Pediatr. 2016;172:194-201.

32. Rutstein SO, Johnson K. The DHS Wealth Index. DHS Comparative Reports No. 6. Calverton: ORC Macro; 2004.

33. SAS Institute Inc. Base SAS 9.4 procedures guide: statistical procedures, second edition. Cary: SAS Institute Inc. USA. SAS Institute Inc. USA; 2013.

34. Demographic and Health Surveys (DHS). What-We-Do > Protecting the Privacy of DHS Survey Respondents: MEASURE DHS; 2018. https:// dhsprogram.com/What-We-Do/Protecting-the-Privacy-of-DHS-SurveyRespondents.cfm Accessed 16 July 2018

35. Baker P, Hawkes C, Wingrove K, Demaio AR, Parkhurst J, Thow AM, Walls $H$. What drives political commitment for nutrition? A review and framework synthesis to inform the United Nations decade of action on nutrition. BMJ Glob Health. 2018;3(1):e000485.

36. Pei $L$, Ren $L$, Yan $H$. A survey of undernutrition in children under three years of age in rural Western China. BMC Public Health. 2014;14(1):121.

37. Kamiya Y. Socioeconomic determinants of nutritional status of children in Lao PDR: effects of household and community factors. J Health Popul Nutr. 2011:29(4):339.

38. Maleta K, Virtanen SM, Espo M, Kulmala T, Ashorn P. Childhood malnutrition and its predictors in rural Malawi. Paediatr Perinat Epidemiol. 2003;17(4): 384-90.

39. Madise NJ, Mpoma M. Child malnutrition and feeding practices in Malawi. Food Nutr Bull. 1997;18(2):1-4.

40. Chirwa EW, Ngalawa HP. Determinants of child nutrition in Malawi. S Afr J Econ. 2008:76(4):628-40.

41. Rahman MS, Howlader T, Masud MS, Rahman ML. Association of low-birth weight with malnutrition in children under five years in Bangladesh: do mother's education, socio-economic status, and birth interval matter? PLoS One. 2016;11(6):e0157814.

42. Ashworth A. Low birthweight infants, infection, and immunity. Nutr Immun Infect Infants Child. 2001:45:121-36.

43. Islam MM. Increasing incidence of infants with low birth weight in Oman. Sultan Qaboos Univ Med J. 2015;15(2):e177.

44. Hviid A, Melbye M. The impact of birth weight on infectious disease hospitalization in childhood. Am J Epidemiol. 2006;165(7):756-61.

45. Rytter MJ, Kolte L, Briend A, Friis H, Christensen VB. The immune system in children with malnutrition—a systematic review. PLoS One. 2014;9(8): e105017.

46. Aheto JM, Keegan TJ, Taylor BM, Diggle PJ. Childhood malnutrition and its determinants among under-five children in $\mathrm{G}$ hana. Paediatr Perinat Epidemiol. 2015;29(6):552-61.

47. McCourt M. At risk for infection: the very-low-birth-weight infant. J Perinat Neonatal Nurs. 1994;7(4):52-64.

\section{Publisher's Note}

Springer Nature remains neutral with regard to jurisdictional claims in published maps and institutional affiliations.

Ready to submit your research? Choose BMC and benefit from:

- fast, convenient online submission

- thorough peer review by experienced researchers in your field

- rapid publication on acceptance

- support for research data, including large and complex data types

- gold Open Access which fosters wider collaboration and increased citations

- maximum visibility for your research: over $100 \mathrm{M}$ website views per year

At $\mathrm{BMC}$, research is always in progress.

Learn more biomedcentral.com/submissions 